\title{
PENERAPAN METODE TIME SERIES DALAM MEMPREDIKSI HASIL PRODUKSI PERTANIAN BERDASARKAN NILAI TREND
}

\author{
A. Sumardin ${ }^{1}$, Mashud $^{2}$ \\ Teknik Informatika STMIK AKBA ${ }^{1}$, Komputerisasi Akuntansi STMIK AKBA ${ }^{2}$ \\ Email: andisumardin@akba.ac.id ${ }^{1}$, mashud@akba.ac.id ${ }^{2}$
}

\begin{abstract}
ABSTRAK
Pengambilan keputusan untuk strategi di masa yang akan datang sangat dipengaruhi oleh penyajian data yang real time melalui proses analisis metode time series. Metode time series (deret berkala atau runtut waktu) adalah metode yang digunakan untuk meramalkan waktu yang akan datang terkait hasil produksi pertanian pada tahun berikutnya. Peramalan time series bertujuan untuk menemukan pola dalam deret data historis dan mengeksplorasikan pola tersebut untuk masa depan. Dalam menghitung nilai trend digunakan metode Semi Average. Hasil penerapan metode Semi Average dengan menggunakan data trend hasil produksi pertanian 8 tahun terakhir mampu memprediksi hasil produksi untuk 1 tahun berikutnya. Grafik trend plot digunakan untuk trend peningkatan atau penuruan produksi komoditi pertanian.
\end{abstract}

Kata Kunci: produksi pertanian, sistem informasi, time series.

\section{ABSTRACT}

Decision making for future strategy almost influenced by realtime data supply through time series method analysis. Time series method (periodic series or time sequence) use to predict future time related upcoming year agricultural product. Time series forecasting intend to figure out pattern of sequence hystorical data and explore those for future time. Semi average methode be used to calculate the trend value. The result of this method engage the last 8 years data trend to predict agriculutural production in upcoming one year. The graphic shows whether production are rised or decreased.

Keywords: agricultural production, information system, time series.

\section{Pendahuluan}

Sistem monitoring hasil pertanian pada Kabupaten Tana Toraja masih disajikan dalam bentuk Microsoft Exel dan dinilai kurang efektif dan efisien karena masih membutuhkan waktu yang lama dan tentunya masih sangat terbatas dalam hal proses pengaksesan informasi oleh berbagai pihak yang berkepentingan. Pentingnya informasi mengenai hasil produksi pertanian, peranan teknologi informasi dengan sistem informasi berbasis web sebagai salah satu ilmu terapannya, memiliki kontribusi yang besar dalam menyediakan sebuah informasi. Sistem informasi monitoring hasil produksi pertanian tanaman jangka pendek berbasis web dirancang dengan tujuan untuk menghasilkan suatu sistem monitoring berbasis web guna mempermudah para staf dan penyuluh pertanian dalam proses pemantauan hasil produksi pertanian tanaman jangka pendek di setiap kecamatan. Selain dari itu aplikasi ini dapat menampilkan informasi data hasil pertanian dalam bentuk statistik sehingga lebih memudahkan dalam melihat perkembangan hasil produksi pertanian.

Penelitian terkait [1] menerapkan teknologi sistem informasi geografis untuk memetakan distribusi hasil produksi pertanian disetiap kecamatan. Informasi peningkatan maupun penurunan hasil produksi pertanian tiap komoditi pada masing-masing daerah disajikan dalam 
bentuk grafik yang dapat memudahkan dinas terkait dalam memutuskan kebijakan.

\section{Tinjauan Pustaka}

\subsection{Sistem Informasi}

Menurut Sutabri [3], sistem informasi adalah suatu sistem didalam suatu organisasi yang mempertemukan kebutuhan pengolahan transaksi harian yang mendukung fungsi operasi organisasi yang bersifat manajerial dengan kegiatan strategi dari suatu organisasi untuk dapat menyediakan laporan-laporan yang diperlukan oleh pihak luar tertentu.

Sistem informasi sebagai suatu sistem yang dapat menghasilkan informasi yang dibutuhkan secara optimal. Proses pengolahan data dapat dilakukan secara efektif dan menghasilkan peningkatkan kualitas informasi dalam artian dapat membantu suatu organisasi mengoptimalkan seluruh kegiatan atau proses yang sedang berlangsung.

\subsection{Produksi Pertanian}

Produksi dapat didefinisikan sebagai suatu proses yang menciptakan atau menambah nilai/guna atau manfaat baru. Guna atau manfaat mengandung pengertian kemampuan barang atau jasa untuk memenuhi kebutuhan manusia. Jadi produksi meliputi semua aktivitas menciptakan barang dan jasa [2]. Sesuai dengan pengertian produksi di atas, maka produksi pertanian dapat dikatakan sebagai suatu usaha pemeliharaan dan penumbuhan komoditi pertanian untuk memenuhi kebutuhan manusia. Pada proses produksi pertanian terkandung pengertian bahwa guna atau manfaat suatu barang dapat diperbesar melalui suatu penciptaan guna bentuk yaitu dengan menumbuhkan bibit sampai besar dan pemeliharaan. Dalam proses produksi pertanian dibutuhkan bermacam-macam faktor produksi seperti tenaga kerja, modal, tanah dan manajemen pertanian. Tenaga kerja meliputi tenaga kerja dalam keluarga dan luar keluarga

\subsection{Time Series}

Time series adalah data yang dikumpulkan dari waktu kewaktu untuk menggambarkan perkembangan produksi, harga, hasil penjualan, jumlah personil, penduduk, jumlah kecelakaan dan lainlain. Analisis data berkala memungkinkan untuk mengetahui perkembangan suatu atau beberapa kejadian serta hubungan/ pengaruhnya terhadap kejadian lainnya [4].

Dari suatu runtut waktu akan dapat diketahui pola perkembangan suatu peristiwa, kejadian atau variabel. Jika perkembangan suatu peristiwa mengikuti suatu pola yang teratur, maka berdasarkan pola perkembangan tersebut akan dapat diramalkan peristiwa yang bakal terjadi dimasa yang akan datang. Jika nilai variabel atau besarnya gejala (peristiwa) dalam runtut waktu (serangkaian waktu) diberi simbol Y1, Y2, ..Yn dan waktuwaktu pencatatan nilai variabel (peristiwa) diberi simbol $\mathrm{X} 1, \mathrm{X} 2$, ..Xn maka rutut waktu dari nilai variabel $\mathrm{Y}$ dapat ditunjukan oleh persamaan $Y=f(X)$ yaitu besarnya nilai variabel $\mathrm{Y}$ tergantung pada waktu terjadinya peristiwa itu

\section{Metode Perancangan \\ 3.1 Use Case Diagram}

Use case diagram admin pada gambar 1 dapat dijelaskan bahwa admin pada sistem ini dapat mengolah data-data yang ada pada sistem seperti menampilkan trend plot, menampilkan trend produksi, menampilkan rekapitulasi hasil produksi, mengolah hasil produksi, mengolah data periode tanam/panen, mengolah komoditi, mengolah data kecamatan dan mengolah data user account. Selain itu, use case diagram user pada gambar 2 dapat di lihat bahwa user pada sistem ini hanya dapat mengakses menu yang ada pada sistem seperti menampilkan trend plot, menampilkan rekapitulasi hasil. 


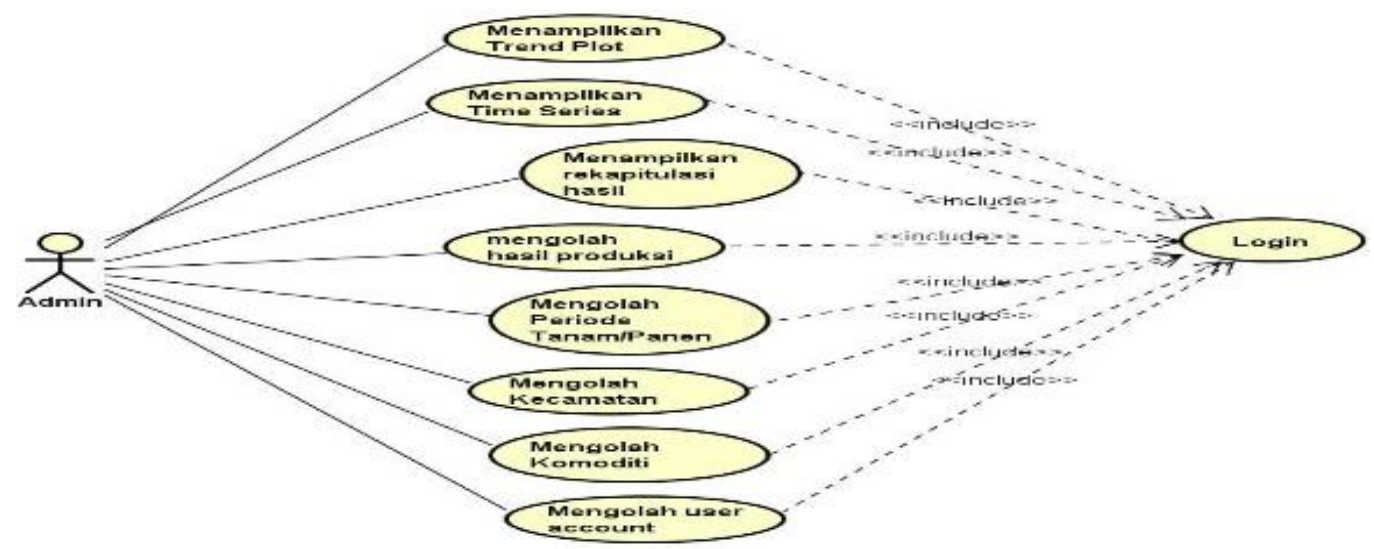

Gambar 1 Use case diagram Admin

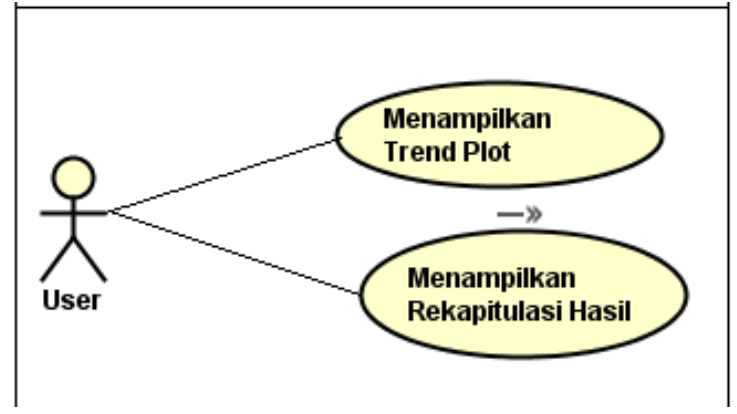

Gambar 2 Use case diagram User

\subsection{Relasi Tabel}

Relasi tabel merupakan kumpulan dari beberapa tabel yang saling terhubung yang nantinya digunakan untuk mendapatkan keluaran sesuai dengan yang di inginkan, seperti ditunjukan pada gambar 4.

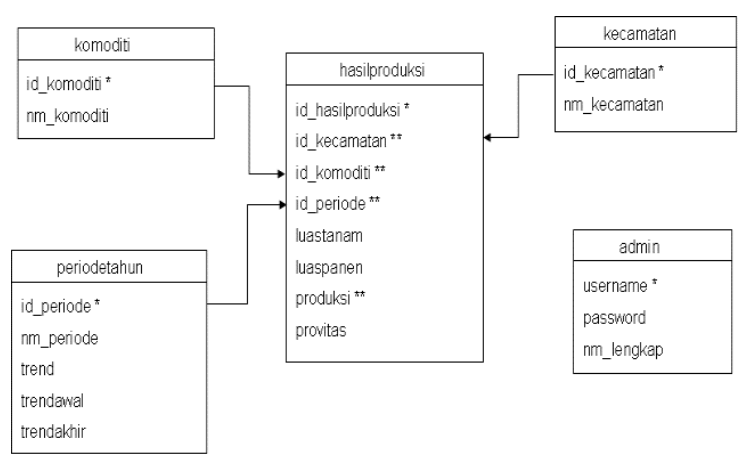

Gambar 4 Relasi Tabel

\section{Hasil dan Pembahasan}

Hasil implementasi penelitian berdasarkan analisis yang telah dilakukan yang mencakup implementasi sistem serta tahap-tahap pengujian dari sistem yang telah dibuat untuk mengetahui tingkat keberhasilan dari sistem tersebut

a. Hasil perbandingan pengujian manual dan sistem

Tabel 1 Hasil Perbandingan Pengujian

\begin{tabular}{|c|c|c|c|c|c|c|}
\hline \multirow{3}{*}{ 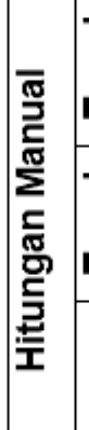 } & 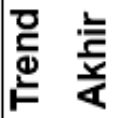 & \begin{tabular}{|l} 
\\
$\infty$ \\
$\infty$ \\
$\infty$ \\
$\infty$
\end{tabular} & \begin{tabular}{l}
$\infty$ \\
\multirow{2}{\infty}{} \\
$\infty$ \\
$\sigma$
\end{tabular} & $\frac{\bar{\sigma}}{\bar{n}}$ & 囬 & 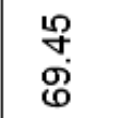 \\
\hline & 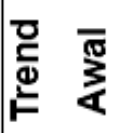 & $\begin{array}{l}0 \\
\infty \\
0 \\
\infty \\
\infty\end{array}$ & $\begin{array}{l}\widehat{\infty} \\
\text { ơ } \\
\text { ô }\end{array}$ & 号 & 足 & $\begin{array}{l}\mathscr{0} \\
\tilde{6} \\
0\end{array}$ \\
\hline & 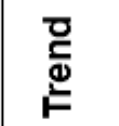 & 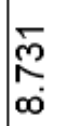 & $\begin{array}{l}\mathscr{0} \\
\mathscr{0} \\
\mathscr{G}\end{array}$ & $\frac{\check{T}}{\check{r}}$ & 只 & $\begin{array}{l}80 \\
6 \\
6\end{array}$ \\
\hline \multirow{3}{*}{ 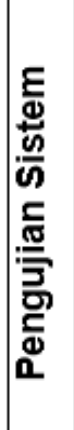 } & 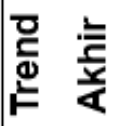 & $\mid$\begin{tabular}{l}
\multirow{\infty}{*}{} \\
$\infty$ \\
$\infty$ \\
$\infty$
\end{tabular} & $\begin{array}{l}\text { ơ } \\
\text { o }\end{array}$ & 苂 & 市 & $\begin{array}{l}\text { ஸิ } \\
\text { ஸ் }\end{array}$ \\
\hline & 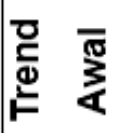 & $\begin{array}{l}\infty \\
\infty \\
\infty \\
\infty \\
\infty\end{array}$ & $\begin{array}{l}\infty \\
\infty \\
\tilde{d}\end{array}$ & $\begin{array}{l}\bar{c} \\
0 \\
0\end{array}$ & 遂 & $\begin{array}{l}\mathscr{6} \\
\mathscr{0} \\
0\end{array}$ \\
\hline & 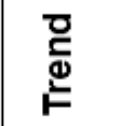 & 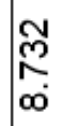 & $\begin{array}{l}0 \\
0 \\
\mathscr{O} \\
\mathscr{0}\end{array}$ & $\frac{\check{T}}{\check{N}}$ & 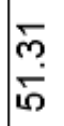 & 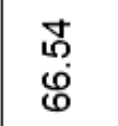 \\
\hline \multicolumn{2}{|c|}{ 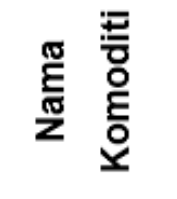 } & 帝 & 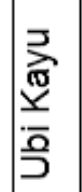 & 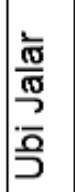 & $\mid \frac{\bar{\sigma}}{\overline{0}}$ & 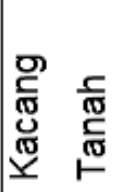 \\
\hline & 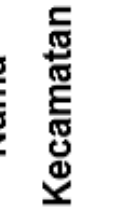 & 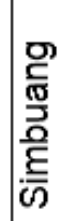 & 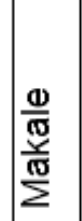 & \begin{tabular}{|l|}
$\overline{\bar{g}}$ \\
$\frac{\mathrm{D}}{\mathrm{O}}$ \\
$\mathrm{C}$ \\
$\overline{\mathrm{D}}$ \\
$\mathrm{O}$
\end{tabular} & 号 & 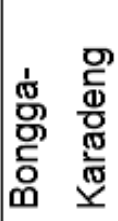 \\
\hline
\end{tabular}




\section{b. Trend Plot}

trend plot merupakan menu yang digunakan untuk menampilkan perkembangan hasil komoditi pada setiap tahun dari tiap-tiap kecamatan. Melalui menu ini pengguna akan mendapatkan informasi hasil pertanian per kecamatan setiap tahunnya. Hasil dari menu ini akan disajikan dalam bentuk grafik.

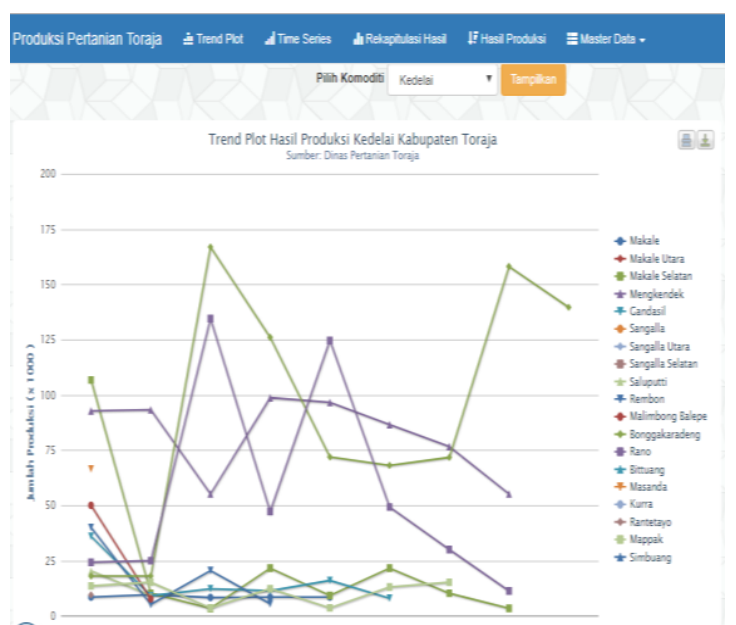

Gambar 5 Trend Plot Hasil Produksi

\section{c. Time Series}

Menu time series merupakan halaman yang digunakan untuk menampilkan hasil komoditi berdasarkan kecamatan dan jenis komoditi. Melalui menu ini pengguna akan mendapatkan informasi tentang jumlah hasil produksi per tahun dari tiap-tiap kecamatan serta jumlah trend, trend awal dan trend akhir. Hasil dari menu ini akan disajikan dalam fitur trend hasil produksi yang telah di filter.

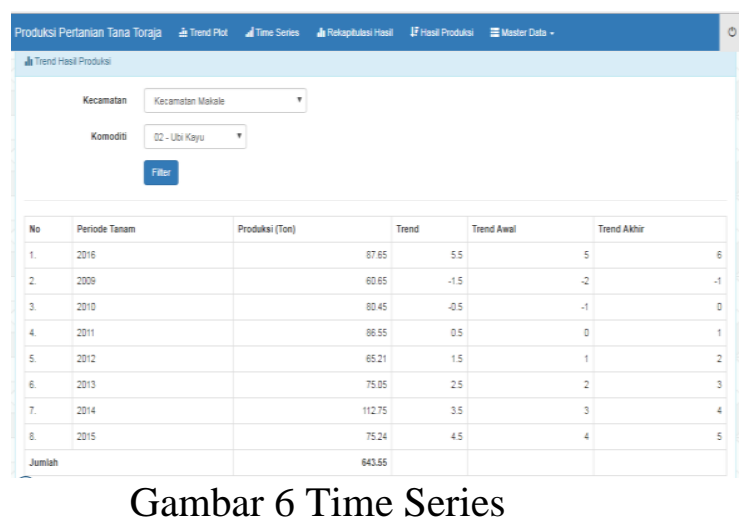

d. Rekapitulasi Hasil

Menu rekapitulasi hasil merupakan tampilan yang digunakan untuk menampilkan hasil hasil pertanian berdasarkan periode tahun dan jenis komoditi. Informasi yang dihasilkan berupa data produksi pertanian tiap tahun dan tiap komoditi dari masing-masing kecamatan. Informasi berupa luas tanam (Ha), luas panen (Ha) dan hasil produksi (Ton) serta produktivitas (Ton) dan ditampilkan juga informasi total dari masing-masing poin tersebut.

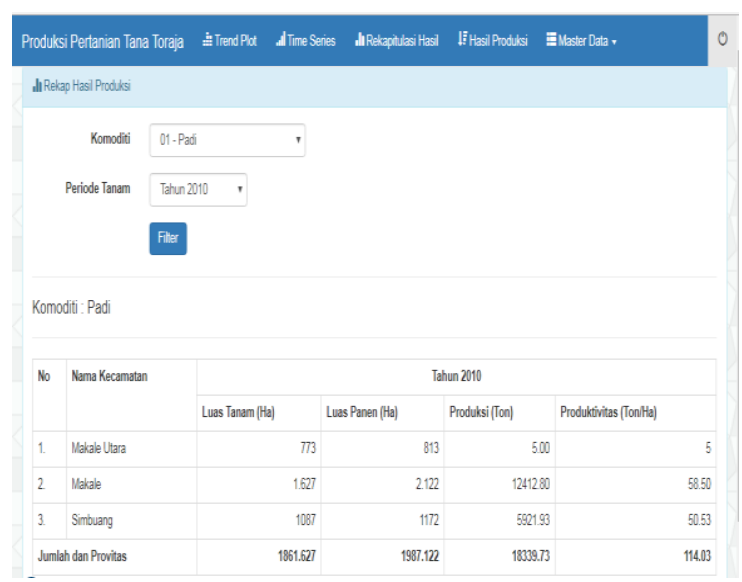

Gambar 7 Rekapitulasi Hasil

\section{e. Hasil Produksi}

Menu hasil produksi pertanian merupakan tampilan yang digunakan untuk menginput serta menampilkan data panen yang ada pada setiap kecamatan. Pada menu hasil produksi terdapat 2 submenu yaitu daftar hasil produksi yang digunakan untuk menampilkan hasil produksi dan Add hasil produksi digunakan untuk menginput data hasil produksi. Melalui form ini pengguna akan mendapatkan informasi tentang jumlah produksi pertanian berdasarkan luas tanam, luas panen, jumlah produksi dan provitas per tahun pada tiap-tiap komoditi di masingmasing kecamatan. Hasil dari menu ini akan disajikan dalam fitur rekapitulasi yang telah difilter. 


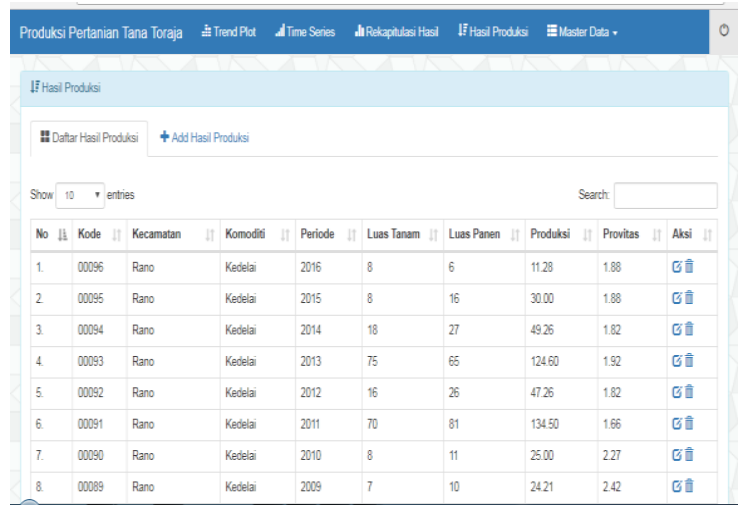

Gambar 8 Hasil Produksi

\section{f. Script Menu Time Series}

Script pada menu time series berfungsi untuk menampilkan trend hasil produksi. Hasil dari menu ini akan disajikan dalam fitur trend hasil produksi yang telah di filter.

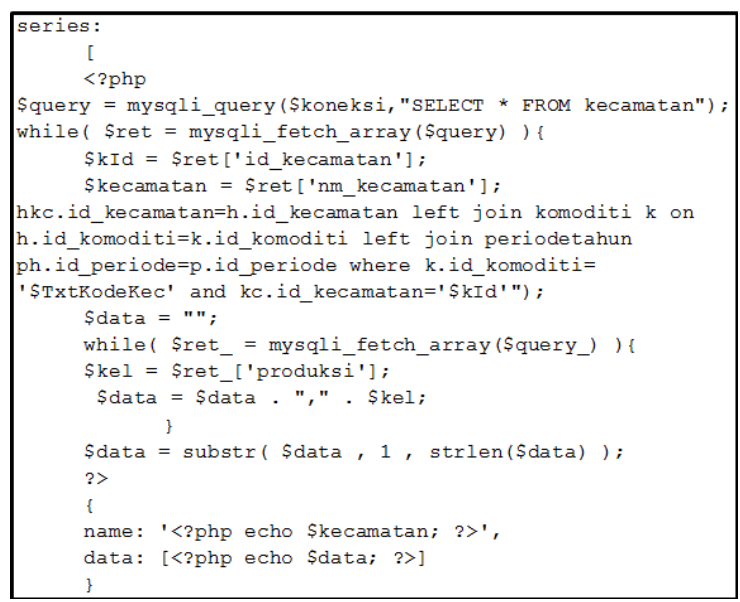

Gambar 9 Script Time Series

Penjelasan : Listing pada gambar 9 \$kcmtn=mysqli_query(\$koneksi,"select * from kecamatan"); merupakan suatu perintah yang digunakan untuk menampilkan data yang ada pada tabel kecamatan . \$query_= mysqli _query \$koneksi,"select h.*,kc.nm_kecamatan, k.nm_komoditi, p.* from kecamatan kc left join hasilproduksi hkc. id_ kecamatan $=$ h.id_ kecamatan left join komoditi $\mathrm{k}$ on h.id_ komoditi=k.id_komoditi left join periodetahun ph.id_periode $=$ p.id_periode where k.id_komoditi= '\$TxtKodeKec' and kc.id_kecamatan='\$kId"'; berfungsi sebagai perintah untuk menghubungkan data yang ada dalam suatu tabel, yang dimaksud adalah perintah untuk menghubungkan field nm_kecamatan, nm_komoditi, nm_periode. Dari tabel kecamatan yang tergabung ke tabel hasilproduksi

\section{g. Script Trend Plot}

Script menu kecamatan berfungsi untuk menampilkan halaman menu kecamatan. Terdapat tombol search yang berfungsi untuk menampilkan hasil pencarian berdasarkan nama kecamatan.

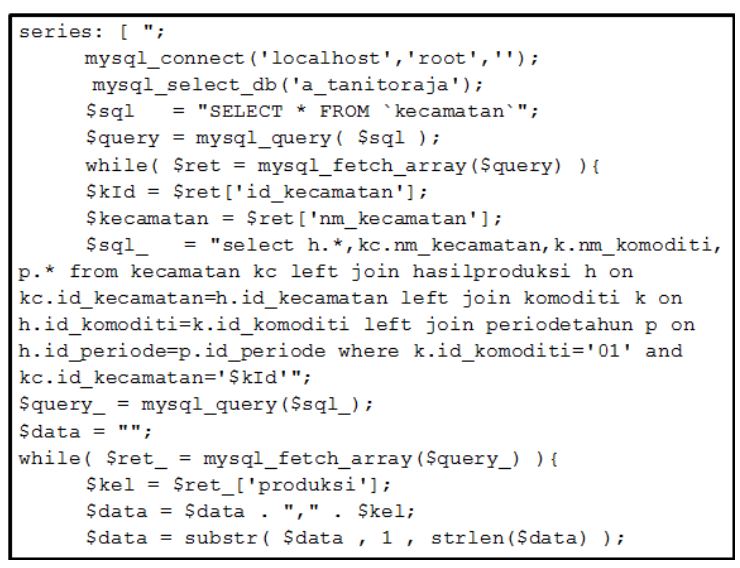

Gambar 10 Script Trend Plot

Penjelasan : Listing pada gambar 10 <'mysql_select_db('a_tanitoraja')'>

berfungsi sebagai perintah untuk menampilkan data yang ada pada database dengan nama "tanitoraja". Dan listing $<$ 'select * from 'kecamatan'> fungsi select adalah sebagai perintah untuk menampilkan data yang ada dalam suatu tabel, yang dimaksud adalah perintah untuk menampilkan tabel yang ada didatabase dengan nama tabel'Kecamatan" yang berisi id_kecamatan dan nm_kecamatan.

\section{Kesimpulan}

Berdasarkan penelitian yang telah dilakukan, dapat disimpulkan bahwa :

a. Sistem informasi monitoring hasil produksi pertanian tanaman jangka pendek dapat membantu dalam proses 
memantau perkembangan hasil produksi pertanian dari tahun ketahun.

b. Berdasarkan hasil pengujian sistem dengan perhitungan manual yang dilakukan pada 5 komoditi menunjukkan bahwa terjadi selisih ratarata sebanyak satu angka. Hal ini disebabkan karena adanya pembulatan pada perhitungan sistem

\section{Daftar Pustaka}

[1] Sumardin, A., \& SN., Arfandi, (2016). Penerapan Sistem Informasi Geografis dalam Pemetaan Produksi Pertanian di Kabupaten Bone. Jurnal Inspiraton Vol.2 No. 2 Desember 2016.

[2] Gumbira, E., \& Haritz, A. I. (2001). Manajemen Agribisnis. Jakarta: Ghalia Indonesia

[3] Muslihudin, Muhamad dan Oktafianto. 2016. Analisis dan Perancangan Sistem Informasi Menggunakan Model Terstruktur dan $U M L$. Andi Offset:Yogyakarta.

[4] Supranto,J. 2000. Statistik Teori dan Aplikasi. Jakarta : Erlangga. 